\title{
Evaluation of the alcoholic extract of Dipteryx alata Vogel almonds and bark in skin wound healing in C57BL6 mice
}

\author{
[Avaliação do extrato alcoólico da casca e da semente da Dipteryx alata Vogel \\ na cicatrização da pele de camundongos C57BL/6]
}

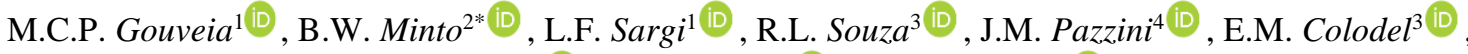 \\ V.C.P. Silva ${ }^{3}$, P.C. Cassino ${ }^{1}$ (D) , L.G.G.G. Dias ${ }^{2}$ (D) \\ ${ }^{1}$ Graduate, Universidade Estadual Paulista, Faculdade de Ciências Agrárias e Veterinária, Jaboticabal, SP, Brasil \\ ${ }^{2}$ Universidade Estadual Paulista, Faculdade de Ciências Agrárias e Veterinária, Jaboticabal, SP, Brasil \\ ${ }^{3}$ Universidade Federal de Mato Grosso, Cuiabá, MT, Brasil \\ ${ }^{4}$ União das Faculdades dos Grandes Lagos, São José do Rio Preto, SP, Brasil
}

\begin{abstract}
The aim of this study was to evaluate the topical application of alcoholic extracts of Dipteryx alata Vogel almonds and bark in skin wound healing in mice. Fifty-four C57BL/6 mice were equally distributed into three groups: Control, Almond, and Bark. A $9 \mathrm{~mm}$ skin fragment was resected from the dorsal region of the animals' thorax. The wounds were submitted to topical application of base cream (vehicle), 10\% hydroalcoholic almond extract, or bark extract twice a day. Macroscopic, histological, and immunohistochemical evaluations were conducted on the 7 th, 14th, and 21st postoperative days. No significant difference was observed regarding skin wound area among groups, with the parameter presenting only a temporal effect on healing $(\mathrm{p}>0.05)$. The almond and control groups exhibited more intense collagenization than the bark group $(\mathrm{p}<0.05)$. Dipteryx alata Vogel showed to be inert in the wound healing process in mice.
\end{abstract}

Keywords: baru, epithelialization, skin wounds, phytotherapic, Leguminosae

\section{RESUMO}

O objetivo deste estudo foi avaliar a aplicação tópica do extrato alcoólico da semente e da casca da Dipteryx alata Vogel na cicatrização de feridas cutâneas, em camundongos. Um total de 54 camundongos C57BL/6 foram utilizados neste estudo, distribuídos em três grupos de 18 animais (controle, semente e casca). Em todos os animais, um fragmento de pele foi ressecado da região dorsal do tórax utilizando-se instrumento de punção de $9 \mathrm{~mm}$ de diâmetro, após o qual foi realizada aplicação tópica de creme base (veículo), extrato hidroalcoólico $10 \%$ de semente ou casca, duas vezes ao dia. As avaliações macroscópica, histológica e imuno-histoquímica foram realizadas no sétimo, $14^{\circ}$ e $21^{\circ}$ dias de pós-operatório. Não foi observada diferença significativa quanto à área da ferida cutânea entre os grupos, apenas um efeito temporal na cicatrização $(P>0,05)$, indicando estágio possivelmente mais avançado desse processo. Porém, na avaliação histológica, os grupos semente e controle apresentaram colagenização mais intensa que o grupo casca $(P<0,05)$. Dipteryx alata Vogel mostrou-se inerte no processo de cicatrização de feridas em camundongos.

Palavras-chave: baru, epitelização, ferida cutânea, fitoterápico, Leguminosae

\section{INTRODUCTION}

Skin wounds represent one of the most important pathological processes in humans and animals (Han and Ceilley, 2017). They have a variety of causes and are often classified based on their underlying origin as acute and chronic (Farzaei et al., 2014). Skin wounds are related to considerable interferences in the quality of life, pain, and long-term hospitalization, in addition to high costs (Nussbaum et al., 2018).

*Corresponding author: brunowminto@gmail.com

Submitted: February 3, 2021. Accepted: August 20, 2021 
The healing of these wounds is a complex and dynamic process capable of restoring cellular structures that culminate in tissue integrity (Campos et al., 2007). Although tissue repair is a systemic process, it is necessary to favor ideal local conditions with the removal of devitalized tissue and exudates, the promotion of wound bed revascularization, and the creation of a controlled humid environment for successful wound repair (Negua et al., 2018). In this context, topical skin wound therapy is essential in making this process viable. Despite the numerous techniques and products tested and used in skin wound healing, a gold standard remains unavailable (Giannoudis and Tosounidis, 2020).

Many plants in tropical and subtropical regions have been studied regarding their potential for healing. Dipteryx alata Vogel, popularly known as Baru, belongs to the Leguminosae family and is one of the native species of the Brazilian Cerrado that has significant nutritional and pharmacological potential (Tambarussi et al., 2017).

In folk medicine, baru is indicated for bronchitis, dysentery, pain, flu, snakebites, and cough (Bieski et al., 2012). However, only the activity of $D$. alata tree bark against snakebites has been scientifically evidenced (Ferraz et al., 2014). Recent studies with the baru almond have shown a potential for antimicrobial activity and effects on hyperlipidemia and oxidative stress in Wistar rats (Fernandes et al., 2015; Reis et al., 2018). Phytochemical investigations with Dipteryx alata Vogel have demonstrated that baru almonds contain phenolic and antioxidant compounds (Lemos et al., 2012; Santiago et al., 2018). Additionally, flavonoids and polyphenols were found in another in vitro and in vivo study assessing the safety of Dipteryx alata Vogel (Esteves-Pedro et al., 2012). Triterpenes, isoflavones, and phenolic acids were also isolated from the lyophilized hydroalcoholic bark extract of Dipteryx alata Vogel (Puebla et al., 2010). These characteristics might potentially improve the healing process; however, to date, there is no controlled study evaluating the influence of the topical use of Dipteryx alata Vogel in skin wound healing.

The hypothesis of this study was that baru does not present delayed properties, but a therapeutic or inert potential for the wound healing process.
Thus, the objective of the present study was to evaluate the effects of alcoholic extracts from baru bark and almonds in skin wound healing in mice through macroscopic, histological, and immunohistochemical analyses.

\section{MATERIALS AND METHODS}

This study was approved by the Ethics Committee on the Use of Animals (CEUA) of the Federal University of Mato Grosso (UFMT), Cuiabá Campus, under Protocol No. 23108.143811/201677.

The samples of Dipteryx alata Vogel plants used in the present experiment were collected on the campus of the Federal University of Mato Grosso (UFMT), in Cuiabá, Brazil (15³6'38.9" S; $\left.56^{\circ} 03^{\prime} 50.5^{\prime \prime} \mathrm{W}\right)$. One plant specimen was deposited in the institution's herbarium under Registration No. 42852 by curator Germano Guarim Neto. The crude alcoholic almond and bark extracts were obtained using the rotoevaporation technique and were diluted in a base cream (vehicle) to a concentration of $10 \%$ for topical administration (Esteves-Pedro et al., 2012).

The alcoholic extracts were prepared from the bark and almonds found inside the dry fruit. After collection, the samples were placed in an oven for 24 hours for moisture removal at a temperature between $45^{\circ} \mathrm{C}$ and $50^{\circ} \mathrm{C}$, after which they were ground. A $70 \%$ hydroalcoholic solution was added to the powder at a 1:3 ratio, and the mixture was stirred manually every 12 hours. Every 5 days, the mixture was filtered through a simple glass funnel containing cotton and completed with a $70 \%$ hydroalcoholic solution at a proportion of $1: 3$, three times consecutively. The crude extract was concentrated at the UFMT Organic Chemistry Laboratory using a rotary evaporator (Fisatom $802^{\circledR}$, São Paulo - SP, Brazil), at a temperature between $50^{\circ} \mathrm{C}$ and $55^{\circ} \mathrm{C}$, for total solvent elimination. After the concentration process, the obtained material, which presented paste form, was then diluted in a base cream to a concentration of $5 \%, 10 \%$, and $15 \%$. In the end, the $10 \%$ concentration was selected due to its optimal density since, at $5 \%$, the extract was too fluid, and at $15 \%$, too dense.

A total of fifty-four C57BL/6 mice, with a mean weight of $20 \mathrm{~g}$, were used in the present study. The 
animals were randomly divided into three groups containing 18 animals each: Control, Almond, and Bark. The mice were submitted to the surgical procedure and, immediately thereafter, base cream (vehicle - Control Group), 10\% hydroalcoholic almond extract (Almond Group), or 10\% hydroalcoholic bark extract (Bark Group) was applied. A macroscopic evaluation was performed on the $7 \mathrm{th}, 14 \mathrm{th}$, and $21 \mathrm{st}$ postoperative days. During the entire experimental period, the animals were kept in polypropylene cages measuring $30 \times 20 \times 13 \mathrm{~cm}$, housed in a room with temperatures ranging between $21^{\circ} \mathrm{C}$ and $28^{\circ} \mathrm{C}$, with no activity restrictions, and fed with autoclaved pelleted commercial food suitable for the species and filtered water ad libitum. The shavings were also autoclaved and changed every three days.

In order to produce the skin wound, the animals were anesthetized intraperitoneally with ketamine (Ketamina Agener ${ }^{\circledR} 10 \%, 50 \mathrm{mg} / \mathrm{kg}$ ) and xylazine (Anasedan ${ }^{\circledR} 23 \%, 3 \mathrm{mg} / \mathrm{kg}$ ). Afterward, they were placed in prone position and the surgical area was subjected to trichotomy and antisepsis. A circular dermo-epidermal segment was resected using a 9 $\mathrm{mm}$ diameter metallic punch in the dorsal region of the thorax. The circular segment of skin was discarded, maintaining the muscular fascia exposed. After hemostasis by local compression, the skin wounds of the animals from each experimental group underwent treatment application in the amount of $0.3 \mathrm{~mL}$. On subsequent days, the wounds were treated with the respective product every 12 hours.

The animals were observed for 21 days for the morphological and morphometric assessment of their cutaneous wounds in the periods of 7, 14, and 21 days after surgery. In the macroscopic analysis, the following criteria were used: occurrence of hemorrhage (absent/present), presence of secretion (absent/present), and epithelialization (complete, partial, or absent). The evaluated data were recorded on a specific sheet, individual for each mouse. In addition, the macroscopic details were photographed using a non-DS 1Ca26491 digital camera. The healing assessment was performed by importing the digital photograph image of the lesion into the ImageJ software and measuring the wound retraction area.
For microscopy evaluation, the wounds were excised, including a $5 \mathrm{~mm}$ margin of healthy skin. Each fragment was fixed on cardboard, placed in glass bottles, and identified individually. The collection process was repeated on days 7,14 , and 21 , with a sampling of six animals per period. After 24 hours of immersion in a $10 \%$ buffered formalin solution, the fragments were incorporated into paraffin blocks. The paraffinembedded samples were cut in a microtome, and the histological sections were processed to a thickness of $2 \mu \mathrm{m}$. Afterward, they were kept overnight in an oven at $37^{\circ} \mathrm{C}$. Subsequently, hydration was performed in increasing dilutions of alcohol, and diaphanization, in xylol, followed by specific staining.

The Hematoxylin and Eosin (HE) staining technique was used to evaluate the epidermis and dermis regarding the presence of mononucleated and polymorphonucleated cells, fibroblasts, vascular proliferation, and hemorrhage. The Picrosirius (Easy Path - Picrosirius Red Staining) method was used to assess collagenization according to collagen fiber type.

The histological sections were analyzed by the same pathologist, without prior knowledge of group identification, under an optical microscope at $400 \mathrm{X}$ magnification. Photomicrographs were taken using the NIS program - Nikon Imaging Software Elements, version 4.30.

The data obtained by HE staining was analyzed using semiquantitative and quantitative methods. The semiquantitative technique was based on vessel intensity and the presence of mononuclear and polymorphonuclear cells, fibroblasts, and hemorrhage. All findings were translated into quantitative variables by index assignment for histological findings, as recommended by Garros et al. (2006), and registered in each animal's individual records. As for the Picrosirius data, several sections were analyzed by optical microscopy under polarized light (Olympus BX$53^{\circledR}$, Japan). The visualization of the collagen fibers through this method allowed the differentiation of collagen type I (yellowishorange to orange and red birefringence) and type III (green or yellowish-green birefringence) (Coleman, 2011). Ten histological fields were selected in each slide and photomicrography was carried out with a digital camera $(5.0 \mathrm{~m})$ at $20 \mathrm{X}$ magnification. The images were analyzed with the 
aid of the ImageJ software, using the Color Threshold plug-in, and the percentage of collagen was determined by automated particle analysis, in which the areas were selected and measured based on color, as described in the literature (Bedoya et al., 2016).

For the immunohistochemical analysis of CD31 (angiogenic index) and A1/A2 (reepithelization), the sections were subjected to specific antibodies. The detection system used followed the manufacturers' instructions (Polymer Kit Leica Biosystems, USA). Cytokeratine Ae1/Ae3 immunostaining data were evaluated through photomicrographs, which were obtained with an optical microscope, at 400X magnification, using the NIS program - Nikon Imaging Software Elements, version 4.30; this analysis evaluated tissue reepithelization. Subsequently, the images were analyzed with the aid of the Image $\triangle \circledR$ software, using the Threshold Colour plug-in, obtaining the percentage of the total wound reepithelialization area through automated particle analysis according to the selection and measurement of the areas based on color.

The angiogenic index for CD31 was determined using the microvascular counting (MVC) technique, as described by Maeda et al. (1995). The areas with the largest number of vessels at lesion depth were analyzed. Any cell or endothelial cell group that was positively stained separately from adjacent microvessels and other connective tissue elements was considered a single vessel, as were vessels containing lumen. The vessels were counted in five previously selected fields with high vascular density at $400 \mathrm{X}$ magnification using a light optical microscope. MVC was conducted twice by a single evaluator, at two different times, and expressed as the mean number of vessels in each case studied.

Descriptive analyses were performed considering the mean and standard deviation values in quantitative variables, and median and mean absolute deviation in qualitative variables. Considering the quantitative variables, the evaluation of the effect of group (bark, control, and almond) and day (7, 14, and 21), as well as their interactions, were assessed by Analysis of Variance (ANOVA). The contrast between treatments within the group and day factors was established using the Tukey test. Meanwhile, the qualitative variables of the histological evaluation were analyzed using the Kruskal-Wallis nonparametric test, as were reepithelization and the number of vessels, which, although quantitative, did not reach homogeneity of variance according to Levene's test. All analyses were conducted using the $\mathrm{R}$ software ( $\mathrm{R}$ Core Team, 2020), adopting a $5 \%$ significance level $(\mathrm{p}<0.05)$.

\section{RESULTS}

Macroscopically, none of the animals' wounds presented hemorrhage or purulent discharge, crusts, or necrosis. There were no differences in wound retraction among the groups, seeing that the statistical means were similar in the three observation periods. The statistical difference found between the 7th, 14th, and 21st postoperative days indicated only a temporal effect on complete healing. The relationship of skin wound area and the effect of time on healing among the groups is shown in Figure 1A.

Histologically, the wounds healed well and were covered with epithelial tissue. Fibrous replacement of the dermis was observed in the three groups. Also, the intensity and quantification of vascular proliferation, assessed by the Hematoxylin \& Eosin (HE) histochemical method, were not statistically different when comparing the variables polymorphonuclear cells, mononuclear cells, fibroblasts, hemorrhage, and vascular proliferation among the control and the Dipteryx alata Vogel (bark and almond) groups on the 7 th, 14th, and 21 st postoperative days ( $p>0.05$ ). Regarding the temporal effect, only the variables fibroblasts, polymorphonuclear cells, and epithelialization showed statistical relevance; a marked presence was noted on the 7 th day, with a progressive decrease on the 14 th and 21 st days after surgery.

The differentiation of collagen fibers I and III by Picrosirius histochemical analysis showed statistical significance for type I collagen fibers in the control and Dipteryx alata Vogel almond groups $(\mathrm{p}<0.05)$, which exhibited better performance when compared to the bark group (Fig. 1B and 2). As for the type III collagen fiber evaluation, the findings were similar in the three experimental groups.

In the intergroup evaluation, CD31 (angiogenesis marker) revealed higher medians in the control and almond groups on the 14th postoperative day, although there was no statistical difference among 
the evaluated moments ( $>0.05$ ) (Fig. 1C). The Ae1/Ae3 (cytokeratin marker) assessment also showed no statistical difference among groups $(\mathrm{p}>0.05)$.
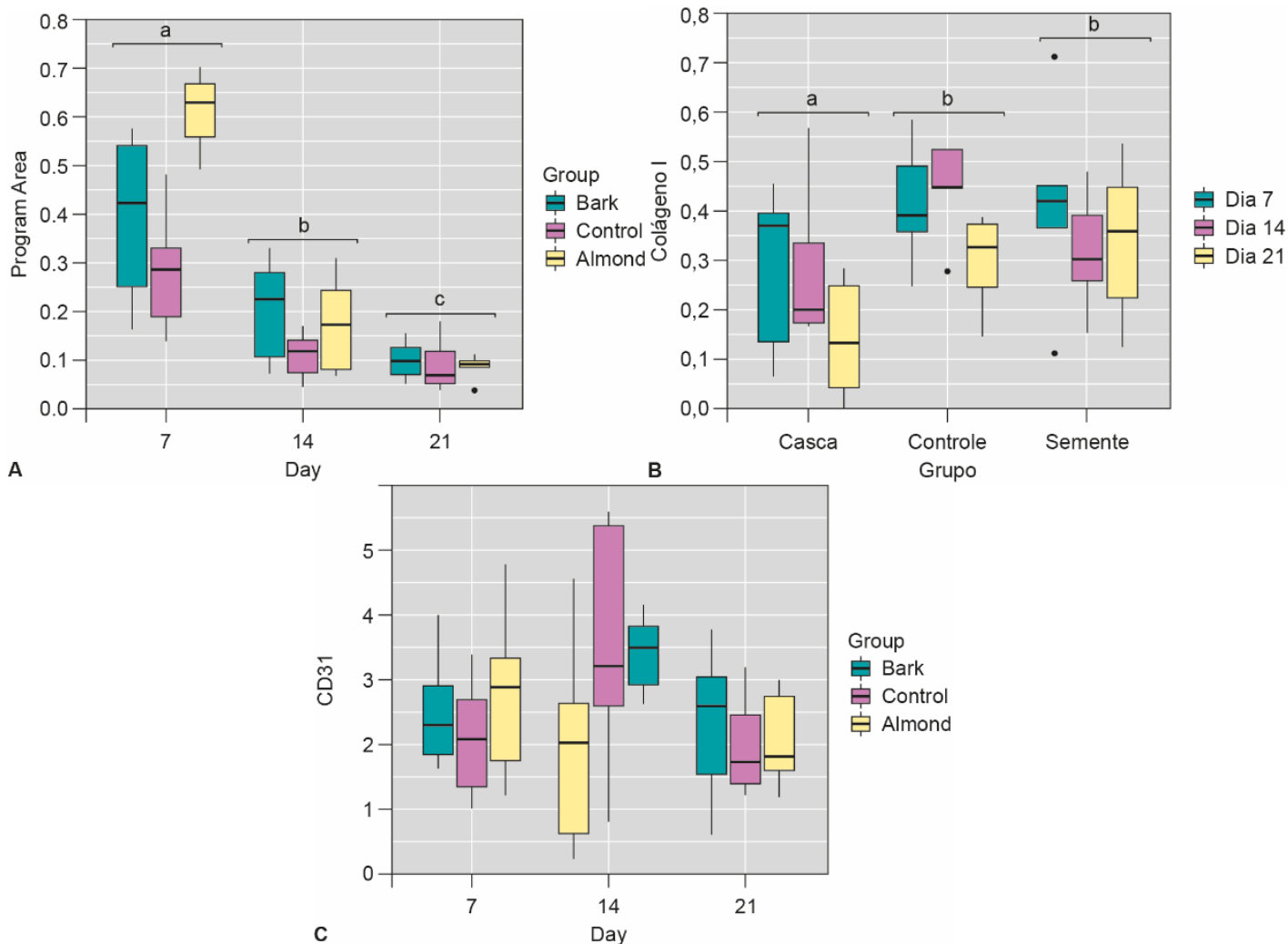

Group

官 Control

官 Almond

Figure 1. (A) Box-plot graph of the medians and standard deviations of the healing area among the bark, control, and almond groups on the 7th, 14th, and 21st postoperative days ( $p>0.05$ ). (B) Box-plot graph of the medians and standard deviations of the collagen fibers (Picrosirius analysis) among the bark, control, and almond groups on the $7 \mathrm{th}, 14 \mathrm{th}$, and $21 \mathrm{st}$ postoperative days. A statistical difference $(\mathrm{p}<0.05)$ was observed between the control and almond groups in relation to the bark group. (C) Box-plot graph of the medians and standard deviations of the CD31 immunohistochemical marker among the bark, control, and almond groups on the 7 th, 14 th, and 21 st postoperative days ( $p>0.05)$.
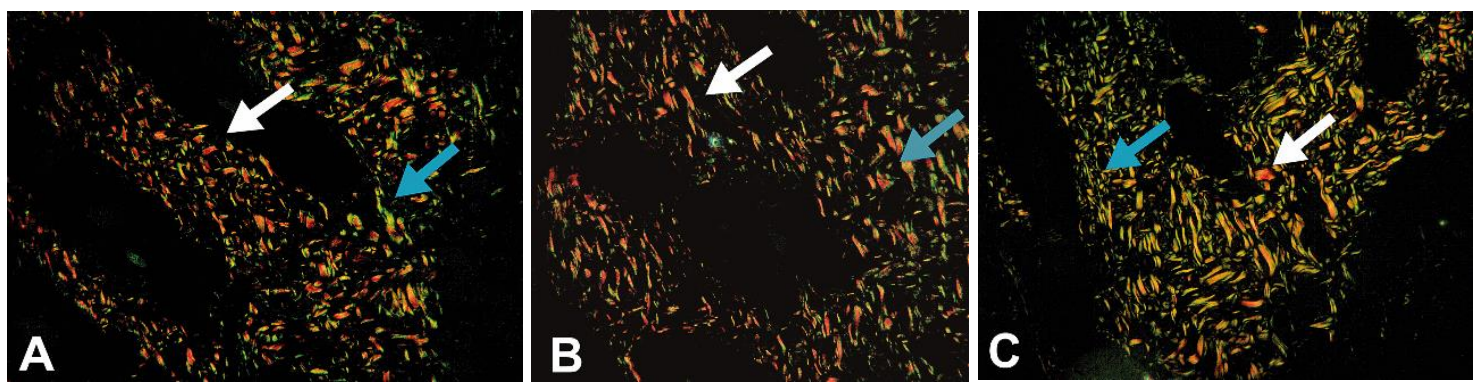

Figure 2. Photomicrographs of the histological aspect of collagenization in the mice on the 14th postoperative day, indicating collagen type I and type III by Picrosirius staining, 400X amplification, Polarized Light Microscopy. The white arrow and red color represent collagen I, and the blue arrow and green color represent collagen III in the control (Fig. 2A), almond (Fig. 2B), and bark (Fig. 2C) groups. Note the predominance of collagen I in the control and almond groups. 


\section{DISCUSSION}

Phytotherapic extracts are often used to promote increments in the healing process of cutaneous wounds (Pazyar et al., 2014). There is evidence of adjuvant anti-inflammatory and antibacterial effects of several plants on the proliferative process, contraction, and nutrition of the wound bed (Raina et al., 2008). In the present study, the use of the phytotherapic agent Baru comprised a potentially new modality of enhancing healing since no negative interference was observed regarding its use.

Although Dipteryx alata Vogel has demonstrated nutritional, pharmacological, and antimicrobial effects (Fernandes et al., 2015; Tambarussi et al., 2017; Reis et al., 2018), to date, there has been a lack of results available in the literature on the potential effects of baru in the wound healing process. The initial hypothesis of this study that the hydroalcoholic extract of Dipteryx alata Vogel could have positive healing effects was not accepted, seeing that the results were not superior to those of the control group. Nevertheless, there is no evidence that the used extracts promote harmful or negative effects on wound healing.

Some phytotherapic agents for topical use have undergone similar investigation, such as the Passiflora edulis extract studied by Garros et al. (2006). In their study, the authors observed no significant effects on skin healing in rats when compared to the control group. However, they suggested a beneficial effect on the healing process by improving collagenization and epithelialization. Their results corroborate those

found herein since there was no significant difference among the groups regarding reepithelization in the Ae1/Ae3 analysis, which evidenced the healing epithelium of the lesions, although the collagenization and presence of fibroblasts among the treated groups was superior.

In the present study, the three analyzed groups presented many fibroblasts in the histological evaluation, mainly on the 7 th postoperative day. Nonetheless, the fibroblast analysis did not show a significant intergroup effect. Although the deposition of type I collagen was better in the baru almond group than the bark group, this result was not sufficient to cause potentially positive interference in the fibroplasia process, which consists of the deposition of collagen by the multiplication of fibroblasts. Similar findings were obtained in the study by Garros et al. (2006), although no significant difference was observed in the surgical wound area between the Passiflora edulis group and the control; the phytotherapic agent showed fibroblastic potential also on the 7th postoperative day, suggesting a beneficial effect on the healing process.

As observed in this study, collagenization and the proliferation of fibroblasts were not significant between groups; however, the histological evaluation showed that the group treated with almonds and control presented better quality. This fact is due to the stimulation of fibroblasts, which may have occurred with the use of the phytotherapic agent.

The superior results of the almond group in the type I collagen evaluation indicate a possibly more advanced stage in the wound healing process, especially considering that type III collagen fibers are gradually absorbed and replaced with type I collagen fibers, increasing the strength, organization, and thickness of the extracellular matrix (Rebolla et al., 2013). It is believed that the active principles of both baru almonds and bark may present some level of stimulation of collagen replacement, with superiority demonstrated by the almond group. The type III collagen assessments revealed similarities between the treated and control groups, thus annulling the chances of increasing or improving initial or early healing. Still, they can confirm neutrality, given that no adverse or impeding effects on healing were observed.

As for the lack of clear evidence concerning the potentiating effects of alcoholic baru extracts on wound healing evaluated in the present study, the neutrality of the active ingredients is evident, which may justify its use as folk medicine so far. There were no signs of inflammation, foreign body reactions, crusting, delayed healing, or the presence of exudate, thus contributing to the safe use of this plant in the formulation of substances for topical use in mice. 
A decreasing correlation of polymorphonuclear cells was observed on the 14th and 21st days compared to the 7 th postoperative day in all groups, although without significant differences among them. Such result may represent a normal and expected progression of the skin healing process since higher concentrations are expected at the beginning of inflammation, followed by gradual reduction (Sanchez Neto, 1993; Zhao et al., 2016).

Regarding vascularization, no intergroup differences were found considering the temporal reduction in vessel intensity, which would also be expected in a normal healing process (Estevão et al., 2009; Zhao et al., 2016). These results corroborate the physiological responses anticipated in a normal acute healing process, although they do not allow to establish any superiority among the treated groups. However, it can be inferred that there was no negative influence on leukocyte and vascular response in the groups treated with the baru extracts.

The use of Dipteryx alata Vogel extracts in the healing process of skin wounds in mice remains open for research, despite previous studies having demonstrated some potential components from baru (Puebla et al., 2010; Esteves-Pedro et al., 2012; Lemos et al., 2012; Santiago et al., 2018). Therefore, further experimental studies regarding their phytochemical, microbiological, and antimicrobial properties are needed. These factors are important for the characterization and identification of potentially healing compounds in medicinal plants (Farzaei et al., 2014). Furthermore, the choice of the phytotherapic extract concentration can directly interfere with the healing results. Thus, the present study poses the question of whether the use of a higher concentration could provide better wound healing results, prompting further dose/effect studies.

\section{CONCLUSION}

The alcoholic extracts of Dipteryx alata Vogel almonds and bark were not negatively related to inflammation, tissue retraction, loss of hair follicles, or infection. Also, they did not show changes in the speed of wound closure, quality of reepithelialization, neovascularization, and collagenization compared to the control group. Baru proved to be inert to the wound healing process in C57BL/6 mice according to macroscopic, histological, and immunohistochemical analyses. 


\section{ACKNOWLEDGEMENTS}

FAPESP (process nº 2018/25061-6).

\section{REFERENCES}

BEDOYA, S.A.O; CONCEIÇÃO, L.G.; VILORIA, M.I.V. et al. Caracterização de colágenos tipos I e III no estroma do carcinoma de células escamosas cutâneo em cães. Arq. Bras. Med. Vet. Zootec., v.68, p.147-154, 2016.

BIESKI, I.G.C.; SANTOS, F.R.; DE OLIVEIRA, R.M. et al. Ethnopharmacology of Medicinal Plants of the Pantanal Region (Brazil). Ecam, v.1, p.36, 2012.

CAMPOS, A.C.L.; BORGES-BRANCO, A.; GROTH, A.K. Wound healing. ABCD, Arch. Dig. Sur., v.20, p.51-58, 2007.

COLEMAN, R. Picrosirius red staining revisited. Acta Histochem., v.113, p.231-233, 2011.

ESTEVÃO, L.R.D.M.; MEDEIROS, J.P.D.; SCOGNAMILLO-SZABÓ, M.V.R. et al. Neoangiogenesis of skin flaps in rats treated with copaiba oil. Pesqui. Agropecu. Bras., v.44, p.406412, 2009.

ESTEVES-PEDRO, N.M.; BORIM, T.; NAZATO, V.S. et al. In vitro and in vivo safety evaluation of Dipteryx alata Vogel extract. BMC Compl. Altern. Med., v.12, p.9, 2012.

FARZAEI, M.H.; ABBASABAD, Z.; SHAMSARDEKANI, M.R., et al. A comprehensive review of plants and their active constituents with wound healing activity in traditional Iranian medicine. Wounds, v.26, p.197-206, 2014.

FERNANDES, D.C.; ALVES, A.M.; CASTRO, G.S.F. et al. Effects of baru almond and Brazil nut against hyperlipidemia and oxidative stress in vivo. J. Food Res., v.4, p.38-46, 2015.

FERRAZ, M.C.; YOSHIDA, E.H.; TAVARES, R.V. et al. An isoflavone from Dipteryx alata vogel is active against the in Vitro neuromuscular paralysis of Bothrops jararacussu Snake Venom and Bothropstoxin I, and prevents venom-induced Myonecrosis. Molecules, v.19, p.5790-5805, 2014.

GARROS, I.D.; CAMPOS, A.C.; TAMBARA, E.M. et al. Extract from Passiflora edulis on the healing of open wounds in rats: morphometric and histological study. Acta Cir. Bras., v.21, p.55-65, 2006.

GIANNOUDIS, P.V.; TOSOUNIDIS, T.H. Acute and chronic infection: Is there a gold standard for management of the wound and bone defect? OTA Int., v.3, p.e068, 2020.

HAN, G.; CEILLEY, R. Chronic wound healing: a review of current management and treatments. Adv Ther., v.34, p.599-610, 2017.

LEMOS, M.R.B.; ALMEIDA SIQUEIRA, E.M.; ARRUDA, S.F. et al. The effect of roasting on the phenolic compounds and antioxidant potential of baru nuts (Dipteryx alata Vog). Food Res. Int., v.48, p.592-597, 2012.

MAEDA, K.; CHUNG, Y.S.; TAKATSUKA, S. et al. Tumour angiogenesis and tumour cell proliferation as prognostic indicators in gastric carcinoma. Brit. J. Cancer, v.72, p.319-323, 1995.

NEGUA, I.; GRUMEZESCU, V.; GRUMEZESCU, A.M. Treatment strategies for infected wounds. Molecules, v.23, p.2309-2392, 2018.

NUSSBAUM, S.R.; CARTER, M.J.; FIFE, C.E. et al. An economic evaluation of the impact, cost, and medicare policy implications of chronic nonhealing wounds. Value Health, v.21, p.27-32, 2018.

PAZYAR, N.; YAGHOOBI, R.; RAFIEE, E. $e t$ al. Skin wound healing and phytomedicine: a review. Skin Pharmacol Physiol., v.27, p.303310, 2014.

PUEBLA, P.; OSHIMA-FRANCO, Y.; FRANCO, L.M. et al. Chemical constituents of the bark of Dipteryx alata Vogel, an active species against Bothrops jararacussu venom. Molecules, v.15, p.8193-8204, 2010.

RAINA, R.; PRAWEZ, S.; VERMA, P.K. et al. Medicinal plants and their role in wound healing. Vetscan, v.3, p.1-6, 2008.

$\mathrm{R}$ Core Team R: A language and environment for statistical computing. R Foundation for Statistical Computing, Vienna, Austria. URL https://www.R-project.org/.2020.

REBOLLA, A.; ARISAWA, E.A.L.S.; BARJA, P.R. et al. Effect of Brassica oleracea in rats skin wound healing. Acta Cir. Bras., v.28, p.664-669, 2013. 
REIS, M.A.; NOVAES, R.D.; BAGGIO, S.R. et al. A Hepatoprotective and antioxidant activities of Oil from Baru Almonds (Dipteryx alata Vogel) in a preclinical model of Lipotoxicity and Dyslipidemia. Ecam, v.1, p.1-11, 2018.

SANCHEZ NETO, R. Morphological and morphometric aspects of tissue repair of the rat cutaneous wound with and without treatment with 2\% papain solution. Acta Cir. Bras., v.8, p.18-23, 1993.

SANTIAGO, G.D.L.; OLIVEIRA, I.G.D.; HORST, M.A. et al. Peel and pulp of baru
(Dipteryx alata Vogel) provide high fiber, phenolic content and antioxidant capacity. Food Sci. Technol., v.38, p.244-249, 2018.

TAMBARUSSI, E.V.; SEBBENN, A.M.; ALVES-PEREIRA, A. Dipteryx alata Vogel (Fabaceae) a neotropical tree with high level of selfing: implication for conservation and breeding programs. Ann. For. Res., v.60, p.243-261, 2017.

ZHAO, R.; LIANG, H.; CLARKE, E. et al. Inflammation in chronic wounds. Int. J. Mol. Sci., v.17, p.2085, 2016. 